\title{
OPEN Author Correction: The prevalence of microsporidia in China: A systematic review and meta- analysis
}

\author{
Luyao Qiu, Wanyuan Xia, Wendao Li, Jing Ping, Songtao Ding \& Handeng Liu
}

Correction to: Scientific Reports https://doi.org/10.1038/s41598-019-39290-3, published online 28 February 2019

In the original version of this Article, Luyao Qiu and Wanyuan Xia were omitted as equally contributing authors. This has now been corrected in the PDF and HTML versions of the paper.

(c) (i) Open Access This article is licensed under a Creative Commons Attribution 4.0 International License, which permits use, sharing, adaptation, distribution and reproduction in any medium or format, as long as you give appropriate credit to the original author(s) and the source, provide a link to the Creative Commons license, and indicate if changes were made. The images or other third party material in this article are included in the article's Creative Commons license, unless indicated otherwise in a credit line to the material. If material is not included in the article's Creative Commons license and your intended use is not permitted by statutory regulation or exceeds the permitted use, you will need to obtain permission directly from the copyright holder. To view a copy of this license, visit http://creativecommons.org/licenses/by/4.0/.

(c) The Author(s) 2019 